\title{
Neuroimaging in Developmental Coordination Disorder
}

\author{
Gelişimsel Koordinasyon Bozukluğunda Nörogörüntüleme
}

\author{
(D) Canan Yıldırım¹, (D) Gönül Acar ${ }^{2}$, (D) Mine Gülden Polat ${ }^{2}$, (D) Emel Mete ${ }^{3}$, (D) Reyhan Kaygusuz4, (D) Canan Günay Yazıc1 ${ }^{2}$ \\ ${ }^{1}$ Atasehir Florence Nightingale Hospital, Clinic of Pediatrics Neurology, Istanbul, Turkey \\ 2Marmara University Faculty of Health Sciences, Department of Physiotherapy and Rehabiltation, Istanbul, Turkey \\ 3Istanbul Medeniyet University Faculty of Health Sciences, Department of Physiotherapy and Rehabiltation, Istanbul, Turkey \\ 4Demiroglu Bilim University Faculty of Health Sciences, Department of Physiotherapy and Rehabiltation, Istanbul, Turkey
}

\begin{abstract}
Developmental coordination disorder (DCD) is a neuromotor disorder of unknown etiology characterized by motor skill disorder, which significantly inhibits the child's ability to perform daily living activities and affects psychosocial well-being. DCD is one of the least understood and studied neuromotor disorders, and little is known about the neural mechanisms underlying motor impairment. This makes it difficult to understand why children with DCD have difficulty in learning motor skills and what is the best intervention to optimize motor functions. With the further development of neuroimaging techniques, the number of neuroimaging studies to understand the underlying mechanisms in children with DCD has increased in recent years. Results from these studies suggest that children with DCD activate different regions of the brain during functional tasks and show differences in white matter microstructure, cerebellum, basal ganglia, parietal lobe, and parts of the frontal lobe (medial orbitofrontal cortex and dorsolateral prefrontal cortex) compared with typically developing children. We believe that these neuroimaging data obtained from numerous studies will contribute to the explanation of neural mechanisms related to impaired motor function in children with DCD.
\end{abstract}

Keywords: Developmental coordination disorder, diffusion tensor imaging, EEG, fMRI, MRI, neuroimaging

$\ddot{O} \mathbf{z}$

Gelişimsel koordinasyon bozukluğu (GKB), motor beceri bozukluğu ile karakterize, çocuğun günlük yaşam aktivitelerini gerçekleştirme yeteneğini önemli ölçüde bozan ve psikososyal iyilik halini olumsuz etkileyen, etiyolojisi bilinmeyen bir nöromotor bozukluktur. GKB'nin etiyolojisini ve GKB'de görülen motor bozukluğun altında yatan nöral mekanizmaları aydınlatan yeterli bilgi ve kanıt mevcut değildir. GKB’li çocuklarda yapılan nörogörüntüleme çalışmalarının sayısı son yıllarda nörogörüntüleme tekniklerinin gelişmesiyle birlikte artmaktadır. Bu çalışmalar, GKB’li çocukların fonksiyonel görevler sırasında beynin farklı bölgelerini harekete geçirdiğini, tipik gelişen çocuklara kıyasla ak madde mikroyapısında, serebellum, bazal ganglionlar, paryetal lob ve frontal lobun bazı bölümlerinde (medial orbitofrontal korteks ve dorsolateral prefrontal korteks) farklılıklar gösterdiğini ortaya koymaktadır. Ayrıca, GKB'nin etiyolojik kökeninin ve patofizyolojisinin aydınlatılmasının uygun tedavi ve müdahale planına karar verilmesinde de kritik öneme sahip olacağı açıktır. Çok sayıda çalışmadan elde edilen bu nörogörüntüleme verilerinin, GKB'li çocuklarda bozulmuş motor fonksiyon ile ilgili nöral mekanizmalarının açıklanmasına katkısı olacağını düşünmekteyiz. Anahtar Kelimeler: Gelişimsel koordinasyon bozuklukları, difüzyon tensör görüntüleme, EEG, fMRG, MRG, nörogörüntüleme

\section{Introduction}

Developmental coordination disorder (DCD) is a neurodevelopmental condition characterized by an inability to perform motor skills at the appropriate age, motor learning difficulties, and coordination disorders. DCD is one of the most common developmental disorders affecting about $6 \%$ of schoolage children. Children with DCD have difficulty in acquiring and performing motor skills related to daily life, school, work, entertainment and play activities (1). Many emotional and psychosocial problems such as anxiety, lack of self-confidence,

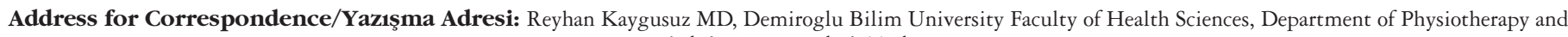
Rehabiltation, Istanbul, Turkey

Phone: +90 5533057467 E-mail: reyhankaygusuz@hotmail.com ORCID: orcid.org/0000-0003-2810-2482

Received/Geliş Tarihi: 29.06.2019 Accepted/Kabul Tarihi: 03.11.2020

${ }^{\circ}$ Copyright 2021 by Turkish Neurological Society

Turkish Journal of Neurology published by Galenos Publishing House. 
anxiety, and depression accompany motor difficulties in children with DCD (2). It is estimated that $75 \%$ of children with DCD continue to experience these difficulties and problems in adulthood in the absence of any intervention (3).

Despite its high prevalence in the population, little is known about the etiology of DCD and how it develops. The developments in neuroimaging techniques in the last 20 years include studies to explain the etiology of DCD. Studies investigating the relationship between motor dysfunction in DCD and neuroanatomic structures are remarkable. In addition, neuroimaging studies are critical for the selection of therapeutic interventions for children with DCD and for evaluating the effectiveness of these interventions.

The purpose of this review was to systematically review the data obtained from existing neuroimaging studies in children with DCD. We believe that a common perspective on DCD will be obtained by compiling studies with different research methods and different results.

\section{Method}

For this review article, the EMBASE, PubMed, PsycINFO, Science of Web, Ebscohost, CINAHL, and ScienceDirect databases were scanned between January $1^{\text {st }}, 2000$, and May 30 ${ }^{\text {th }}, 2019$. In our literature review, the keywords "developmental coordination disorders" and "neuroimaging" and their equivalents as "DCD" and "imaging" were used. Studies with a diagnosis of DCD according to the Diagnostic and Statistical Manual of Mental Disorders (DSM-IV or DSM-V) criteria and using the Movement Assessment Battery for Children (MABC) for motor evaluation were included. Studies with participants aged 5 years or over were included because the minimum age at which DCD can be diagnosed according to the European Academy of Childhood Disability (EACD) guidelines is 5 years. Studies involving serious neurologic disorders such as cerebral palsy were excluded. Pilot studies were included in the review, but case reports and articles that were not published in English were excluded.

In this review, a total of 29 studies, including 12 functional magnetic resonance imaging (fMRI) studies, 4 MRI studies, 5 diffusion tensor imaging (DTI) studies, 6 electroencephalogram (EEG) studies, and 2 functional near-infrared spectroscopy (fNIRS) studies were examined. All of the participants in the studies met the diagnostic criteria for DCD.

Neuroimaging Studies in Children with Developmental Coordination Disorders

\section{1- Functional Magnetic Resonance Imaging}

fMRI is an indirect measure of neural activity that measures blood oxygenation and local blood flow due to changes in the metabolic activity of active neurons. As the amount of oxyhemoglobin increases in the capillaries as a response to neural activity, the amount of deoxyhemoglobin decreases. This change in the ratio of oxyhemoglobin and deoxyhemoglobin can be detected using fMRI (4).

Considering the structural changes in the brain in children with DCD, an increase in activity is observed in the pathway between the inferior parietal cortex in the left hemisphere and both the middle frontal cortex and the anterior cingulate nucleus. In addition, increased activity was found in the pathway between the striatum and parietal cortex in the right hemisphere. It is thought that the reason for this increase in activity is due to weak inhibition mechanisms. Typically, there is a right lateralization tendency in the typically developing children and a left lateralization tendency in DCD. Querne et al. (5) reported that DCD was a condition characterized by the developmental differences of the brain hemispheres in the neurodevelopmental process.

Clumsiness is a common clinical problem in children with DCD. Kashiwagi et al. (6) examined activation areas of the brain with fMRI by giving a visual-motor task to understand the neural mechanism underlying the clumsiness seen with DCD. As a result of this study, it was found that there were also losses in behavioral performance in DCD, in addition to the finding of the study conducted by Querne et al. (5); brain activity was less in the superior and inferior parietal lobes, left posterior parietal cortex, and left post-central gyrus in children with DCD compared with typically developing children. According to the authors, there may be a relationship between the posterior parietal cortex and clumsiness (6). This relationship between the posterior parietal cortex and clumsiness suggests that the same connectivity in the left lateralization hypothesis of Querne et al. (5) is impaired.

Another problem experienced by children with DCD is fatigue in motor activities. The first neuroimaging evidence to support clinical observations on fatigue was provided in the study of Zwicker et al. (7) published in 2010. In this study, it was investigated whether there was a difference in brain activation patterns during fine motor tasks in children with and without DCD. It was found that children with DCD compensated for poor sensory feedback from joints and muscles with visual information and relied more on visual systems for motor tasks. It was also shown that they used the cerebellum lobule VI area more, which was related to visual-spatial processing, and that twice as many areas of the brain were activated to learn a motor task in patients with DCD. For this reason, it is thought that children with DCD also experience cognitive fatigue related to planning, executing, and learning efforts (7).

The study conducted by Zwicker et al. (8) in 2011 was important because it was the first to examine the effects of motor training and changes in brain activation patterns using fMRI scanning in children with DCD. It was shown that it showed lower signaling in all parts of the brain during the learning process. Children with DCD did not show improvement in performing the motor task correctly after 3 days of task training. Less activation was found in the cerebellar-parietal and cerebellar-prefrontal pathways and brain regions associated with visual-spatial learning. The reason for the insufficient learning of motor skills in children with DCD may be due to a neurobiologic disorder.

Children with DCD have longer reaction times than typically developing ones. In a study by Debrabant et al. (9), using fMRI to investigate the neural relationships of motor timing and reaction time in children with and without DCD, it was shown that children with DCD showed decreased signalization in the right dorsolateral prefrontal cortex, the left posterior cerebellum, and the right temporo-parietal junction. Temporal errors increase when visual or auditory stimuli are given simultaneously. 
In addition, the provision of visual stimuli and temporal adjustments do not improve reaction times. It is thought that the failure of children with DCD to respond in the expected time is due to a developmental delay (9). These findings suggest that children with DCD require more effort to perform visual-motor tasks. In a study comparing motor movement patterns that increased cortical activation using fMRI during finger overlap and handshaking tasks, motor movement was found to be weaker in children with DCD compared with typically developing children. According to the analyses performed, no difference was found in handshaking activity in children with DCD, and increases in the activities of the left and right superior frontal gyrus and left inferior frontal cortex were found in the activity of finger overlap task (10). Biotteau et al. (11) reported that only the brain activation patterns of patients with DCD differed from children with developmental dyspraxia and children with both developmental dyspraxia and DCD. These findings suggest that DCD is caused by a neurobiologic mechanism independent of other accompanying clinical conditions.

\section{2- Magnetic Resonance Imaging}

MRI is a non-invasive neuroimaging tool for obtaining detailed images of biologic structures with strong magnetic fields and radio waves without using radiation. An MRI scanner arranges hydrogen atoms in the body with the magnetic field it creates. Radio waves enable these arranged atoms to generate signals that are used to form images. Thus, different images can be obtained to characterize the structure and function of the brain. T1-weighted imaging generally allows differentiation of brain anatomy, white matter and gray matter. T2-weighted imaging, on the other hand, distinguishes brain tissue, and is particularly suitable for diagnosis of inflammation, demyelination, and white matter changes (12).

According to MRI studies performed in children with DCD, abnormal activations in brain areas were found $(8,9,10,13)$. In 2014, Langevin et al. (14) concluded that the orbitofrontal cortex was thinner in people with DCD and this was related to lower scores in motor function tests. In addition, it was found that separation and integration and visual-motor pathway in structural connections were weaker in children with DCD (15).

Although the negative correlation between the left posterior cerebellar lobe gray matter volume and the motor skill score in fine motor activity of drawing curved lines in children with DCD was striking, a positive correlation was found between the gray matter volume of the medial frontal cortex and the error in movements. This study, which was the first to show the relationship between gray matter volume and DCD, showed that there were changes in the cerebellum and parietal lobe associated with DCD (16).

It has been demonstrated that the same neuron network is used in typically developing children and children with DCD, and that the global neuronal connection in children with autism spectrum disorder (ASD) differs from typically developing children and children with DCD. Children with both DCD and ASD differ in terms of both structural and functional characteristics in brain regions related to motor function compared with typically developing children. It has been determined that these differences are caused by the white matter organization in the sensorimotor pathways in children with DCD and microstructural losses in the motor, sensory and cerebellar pathways in ASD. In the same studies, it was found that there was a correlation between these differences and motor function (17).
A decrease in cortical thickness was found in the parietal, frontal, and temporal lobes in children with DCD and attentiondeficit/hyperactivity disorder (ADHD). This study by Langevin et al. (18) in 2015 supported the fact that ADHD and DCD originated from the same neurobiologic markers. This study by Langevin et al. (18) was the first to show that the cortical area of children with motor and attention problems was thinner.

Low birth weight and preterm delivery are thought to be risk factors for DCD. In an MRI study of 7-year-old children born preterm or with low birth weight, white matters of the right and left hemispheres, caudate nucleus, activation of the right and left hippocampus, and motor performance $\left(<5^{\text {th }}\right.$ percentile) using the MABC were evaluated. This study showed that children with lower motor performance had lower right and left hemisphere white matter activation times. However, no relationship was found between right and left hippocampal activations and caudate nucleus volume difference (19). In an MRI study performed on adolescents with low birth weight, with a mean age of 15 years, moderate-toadvanced ventricular dilatation, focal or diffuse corpus callosum thinness, unilateral or bilateral decreased ventricular white matter were found to be associated with lower motor performance (20).

In a study investigating the relationship between congenital stress and childhood DCD, newborns were classified according to congenital MRI abnormalities. MRI abnormalities in newborns with encephalopathy after perinatal asphyxia were classified as class 1: No damage, class 2: Moderate damage, white matter lesions, and class 3: Moderate-severe damage, basal ganglia/ thalamus injury, and focal ischemia. MABC scores were not found $>15^{\text {th }}$ percentile in all children with moderate/severe lesions in neonatal MRI, and in $62 \%$ of children with normal MRI or mild lesions. It was shown that children with moderate/severe lesions, childhood MRI findings and MABC score not more than the $15^{\text {th }}$ percentile significantly overlapped each other (100\%), and that MABC scores were not found $>15^{\text {th }}$ percentile in $47 \%$ of children with mild lesions or without lesions (21).

\section{3- Diffusion Tensor Imaging}

DTI is a neuroimaging method used to measure the amount of displacement (mean diffusion) and relative direction (fractional anisotropy) of the water molecule in axons. Currently, DTI is the only approach that can view the white matter of the brain noninvasively (22). The diffusion parameters used in the DTI method are as follows: Axial diffusion (diffusion of water along the length of the axons) and radial diffusion (water diffusion perpendicular to the axons). An increase in these parameters reflects a better white matter structure for efficient and rapid transfer of information between different brain regions, which supports the development of well-functioning and synchronized neural pathways (23).

It is very important to examine the structure of white matter to understand the neurodevelopmental problems and the underlying causes of these problems in children with DCD. The DTI method has been used in many studies to examine the white matter of the brain. Zwicker et al. (24) compared axial diffusion in the corticospinal tract and thalamic connections in children with DCD and children with normal development and found that axial diffusion was lower in children with DCD. In addition, it was shown by Zwicker et al. (24) that there was a correlation between axial diffusion and MABC. 
According to neuroimaging studies conducted in recent years, permanent neurobiologic changes in the white matter in corticospinal tracts associated with motor planning and cognition have been found in children with DCD. Williams et al. (25) investigated the diffusion of white matter in the corticospinal tract, superior longitudinal fasciculus (SLF) and internal capsule using DTI in their neuroimaging study in children with DCD and found that white matter diffusion in children with DCD was lower than in healthy children. SLF is a structure that provides the connection between the anterior and posterior cortical areas. Any defect in this structure causes problems in functions such as attention control, motor movement memory, and movement planning. In addition, the internal capsule is also related to motor skills. Williams et al. (25) suggested that the reduced axonal diffusion seen in these brain structures might be related to the motor problems seen in children with DCD. In the same study, white matter diffusion in the inferior longitudinal longitudinal fasciculus (ILF) was also examined (25). The ILF provides the connection between the occipital and temporal lobes and also represents the visual ventral pathway. It is known that there are problems in the processing of visual-perceptual information in children with DCD (15). It is thought that visual problems seen in children with DCD may be related to low axonal diffusion in $\operatorname{ILF}(15,25)$. Another study examining the cause of low axonal diffusion detected in the brain structures of children with DCDs is the study of Hyde et al. (26). It has been determined that children with DCD have lower axon diameters and numbers in SLF than normal children and it has been suggested that this may be related to the decrease in motor abilities (26).

DCD can be seen together with other developmental disorders and attention disorder (27). In a neuroimaging study using DTI, Langevin et al. (14) reported that axial diffusion decreased in the parietal lobe above the corpus callosum, as well as the white matter in the SLF in children with diagnoses of DCD and attention disorder. In the same study, they found that there were abnormalities in the connections between the corpus callosum and the primary and somatosensory motor areas of the parietal lobe. The findings in this study supported that DCD and attention disorder shared the same etiology (14).

Comorbidity is also important because it affects research findings in DCD. Children with DCD may have one or more disorders (such as ADHD) and depending on the degree of dysfunction of brain development, DCD may result from different neural mechanisms (28). Therefore, it is important to identify DCD and perhaps distinguish it from other comorbidities when investigating neural correlations. However, there are very few studies on this subject in the literature. More neuroimaging studies are needed on DCD and its comorbidities to fully illuminate this issue (29).

\section{4- Electroencephalogram}

EEG is the oldest functional brain imaging technique and measures the electrical activity of neurons with the placement of electrodes on the scalp. EEG allows visualization of neuronal events occurring at the millisecond level, as well as measuring the current flow emanating from synaptic changes produced by the dendrites of pyramidal neurons. Studies reveal that EEG can directly monitor electrical activities caused by disorders in various structures of the brain. This technique is more preferred in children because it is easier to perform than MRI (30).

According to EEG studies conducted on children with DCD, there is a correlation between EEG signals detected from cortical areas and motor functions. These cortical areas are expressed as follows: Frontal lobe, parietal lobe, and lateral areas of the right and left hemispheres. Overall, these studies compared typically developing children and children with DCD. According to EEG findings, it was determined that children with DCD and typically developing children showed similar performance in EEG, but those with DCD showed different cortical activation patterns $(31,32)$. Motor memory, which is responsible for the simultaneous and temporary storage and processing of the data needed in the execution of complex cognitive tasks, forms the basis of effective problem-solving and planning skills and is supported by visualspatial inputs $(33,34)$. In addition, it has been determined that children with DCD also have deficits in their visual-spatial memory. Tsai et al. (35) gave a task related to visual-spatial memory to children with DCD, examining the EEG findings during this task, and found that children with DCD had longer reaction times compared with their normal peers, and that they allocated less neural resources in the task assessment and response process. Pangelinan et al. (36) also recorded EEG signals of children with DCD while they were drawing a circle with a digital pen on a computer screen, and concluded that children with DCD activated less cortical area and had lower EEG signal amplitudes than their normal peers.

Approximately $50 \%$ of children with DCD also have attention disorder (37). According to some studies, it has been stated that children with DCD have atypical cerebellum and basal ganglia activation and therefore many executive functions including attention are likely to be affected $(38,39)$. In addition, it has been stated in the literature that attention can affect neuromuscular motor performance (40). Based on this hypothesis, Fong et al. (41) evaluated attention levels during motor tasks in children with DCD using EEG and concluded that the relationship between attention and motor performance could be better-determined thanks to EEG signals, which can be obtained instantly during simple and complex motor tasks. According to the data of this study, it was found that the motor performances and EEG signals of children with DCD were lower than their normal peers, and there was a positive relationship between motor performance and EEG (41).

It is known that children with DCD have difficulties in motor skills that require bimanual activity (42). Bimanual coordination is based on the functional bonding between the motor regions of both brain hemispheres via the corpus callosum. Therefore, bimanual coordination provides an important opportunity to investigate possible dysfunctions in brain communication (43). Blais et al. (44) examined both inter-hemisphere and intra-hemisphere brain activities of children with DCD during bimanual activities using EEG. It was found that interhemispheric connections were less in children with DCD compared with their normal peers. In this study, it was noted that the performance of repetitive motor tasks did not increase the intrahemispheric connections of children with DCD. The findings of this study provide new neuroimaging evidence that children with DCD display different motor behaviors compared with their normal peers. It is emphasized that atypical 
brain development in children with DCD may result from the motor inhibition information carried between hemispheres, and more studies should be conducted to investigate the structure of the corpus callosum, which can be involved in atypical interhemispheric communication, to better understand the neural connections of DCD (44). It was stated by different authors in the literature that movement stability decreased due to involuntary movements that children with DCD showed during motor activities, and this might be caused by the lack of motor inhibition $(45,46,47)$.

\section{5- Near-infrared Spectroscopy/Functional Near-infrared Spectroscopy}

Although NIRS was developed to measure cerebral oxygenation, it is also called fNRIS. fNIRS is a non-invasive neuroimaging technique used to measure changes in the concentration of oxyhemoglobin and deoxyhemoglobin in blood during neuronal activation by sending infrared rays in the wavelength range of $700-1300 \mathrm{~nm}$. It is a suitable neuroimaging method for use in studies analyzing brain functions by experimental protocols involving motor activity in children with DCD. fNIRS shows similarities with fMRI, but it is less costly than fMRI and can also be performed with a portable device (48).

There are only two studies conducted with fNIRS on children with DCD. In the first of these studies, two groups of children with DCD and typically developing children were given the task of matching cards according to their colors, shapes, and numbers, and during the task, the dorsolateral prefrontal cortex of the children was examined using fNIRS. Dorsolateral prefrontal cortex activation was found to be higher in children with DCD compared with typically developing children. Koch et al. (49) suggested that children with DCD made more effort to minimize the margin of error behaviorally, and therefore activation in the dorsolateral prefrontal cortex increased in a compensatory manner. In the second fNIRS study, Caçola et al. (50) investigated whether there was a difference in terms of the cortical activation areas between children with DCD and typically developing children during motor tasks given to evaluate visual-motor perception and writing skills. They found that less cortical area was activated and these activation areas were mostly ipsilateral in children with DCD. The fact that children with DCD use more ipsilateral paths may be due to corpus callosum disorders seen in children with DCD (51). By using advanced neuroimaging techniques such as fNIRS, these atypical neural connections seen in DCD can be analyzed better. Therefore, more studies using advanced neuroimaging techniques in children with DCD are needed.

\section{Discussion}

According to the results obtained from this literature review, it is seen that children with DCD show different neural activation patterns compared with typically developing children during motor tasks.

\section{Electroencephalogram}

According to most EEG studies included in the review, the EEG values for cortical activation of children with DCD are lower than the typically developing children. However, in one study, the EEG activation rate of children with DCD was found to be high
(52). The reason for this was claimed that the high EEG activation rate could be due to compensation for the difficulties in perceptualmotor and executive functions while performing movements (52). According to the EEG studies included in the review, although the reaction time of children with DCD to a given motor task was delayed compared with children with typical development, EEG values obtained from the frontal and central regions of the brain were also found to be lower $(31,53)$. The reason for this is that children with DCD engage less neural resources $(33,41,44)$.

\section{Functional Magnetic Resonance Imaging}

According to the fMRI studies included in the review, it was found that children with DCD had lower activation in the left parietal cortex, cerebellum, and basal ganglion regions compared with children with typical development, and that there were atypical connections between the sensory-motor cortex, cerebellum, and basal ganglia areas $(54,55,56)$. The left parietal lobe is the brain region responsible for three-dimensional body perception, providing somatosensory and visual information necessary for hand-eye coordination, and perception of shape, touch, and pressure $(57,58)$. The cerebellum and basal ganglia are responsible for motor movement planning, muscle tone control, and body balance. In functional disorders of the parietal region, although there were disturbances in body perception, touch, and pressure sensations, problems in movement planning, muscle tone, and body balance were seen in the cerebellum and basal ganglia disorders (59). In studies conducted with children with DCD, it was stated that these children had problems in body perception, hand-eye coordination, body balance, pressure, and touch senses (60). fMRI studies also support these results. In addition, it was observed that children with DCD had developmental disorders in their mirror neuron systems. This situation also explains why children with DCD have more problems with motor imagery than typically developing children (61). See Table 1 for a summary of the research findings.

\section{Magnetic Resonance Imaging}

According to the MRI studies in the review, it has been observed that the gray matter volume of the patients with DCD is lower than the typically developing children, but also the cortical thickness is lower. In addition, it is stated that this atypical brain development may be associated with motor dysfunction $(14,16,18)$. However, some children with DCD who take part in MRI studies are children with a preterm history. It is not possible to generalize the results obtained with MRI on brain gray matter because the sample groups in the studies are heterogeneous and the number of studies is low.

\section{Diffusion Tensor Imaging}

DTI is the only neuroimaging method that can analyze the white matter of the brain. According to the DTI studies in the review, the white matter structure of children with DCD is different from that of typically developing children. The amount of axial infusion in the visual-motor pathways of the brain, parietal, and frontal cortex is lower in children with DCD compared with children with typical development $(15,24)$. This atypical white matter structure causes negative effects on motor planning and cognition in children with DCD (25). 
Table 1. Summary of study findings in the literature on neuroimaging

\section{First author,} journal, year, country

Querne et al. (5),
Brain Res, 2008,

France

\section{Participants (number, age range, mean age)}

DCD: 9

Age: 8.0-12.9 (9.9 \pm 1.8$)$

TDC: 10

Age: 8.2-11.6 (10.0 \pm 1.1$)$

Kashiwagi et al. (6), Neuroreport, 2009, Japan
Inclusion and exclusion criteria

\section{Neuroimaging technique}

\section{Neuroimaging results}

DCD: Having a

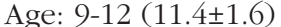

TDC: 12

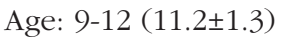

diagnosis of DCD

according to DSM-IV

criteria

Not having neurological

and psychiatric disorders

(e.g. cerebral lesion,

ADHD)

IQ $>80$
DCD: Having a

diagnosis of DCD

according to DSM-IV

criteria

MABC $<15^{\text {th }}$ percentile

IQ $>90$
In children with DCD compared to TDC: Increased activation in the left hemisphere in the middle frontal cortex, anterior cingulate cortex, and inferior parietal cortex; decreased activation in the striatum and parietal cortex in the right hemisphere

Less activation was found in the left parietal cortex and left postcentral gyrus in the group with DCD compared to the TDC group. Similar activation rates were observed in both groups in the cerebellum and basal ganglia areas

Although both groups were given the same motor tasks, it was observed that different areas were activated in both groups.
DCD: MABC- $\leq 16$ th percentile

DCD: 7

Zwicker et al. (7), Pediatrics, 2010, Canada
Age: $8-12(10.8 \pm 1.5)$

TDC: 7

Age: 8-12 (10.9 \pm 1.5$)$
TDC: MABC-2

$>25^{\text {th }}$ percentile

IQ $>80$

Not having a diagnosis of ADHD
More cortical activation was detected in the left parietal lobe, right middle frontal gyrus, right superior temporal gyrus, right cerebellar lobe areas in DCD group compared to the TDC group, while in the TDC group, more cortical activation was detected in the left superior and inferior frontal gyrus than in the DCD group

DCD: MABC- $2 \leq 16^{\text {th }}$

percentile

Zwicker et al. (8), Int J Dev Neurosci, 2011, Canada

Age: $8-12(10.8 \pm 1.5)$

TDC: 7

Age: 8-12 (10.9 \pm 1.5$)$

DCD: 17

Debrabant et al. (9),

Res Dev Disabil, 2013, Belgium

Age: $7-10(9.4 \pm 0.6)$

TDC: 17

Age: 7-10 (9.2 \pm 0.9$)$

percentile
The DCD group showed less cortical activation in the cerebellar, parietal and frontal areas than the TDC group
fMRI

MRI

During motor tasks, less cortical activation was found in the cerebellar areas in the DCD group compared to the TDC group
TDC: $M A B C-2>25^{\text {th }}$

IQ $>80$

Not having a diagnosis of ADHD

DCD: $\mathrm{MABC}-2 \leq 5^{\text {th }}$

percentile

TDC: $M A B C-2>16^{\text {th }}$

percentile

IQ $>85$

Not having a diagnosis of ADHD
DCD: 7

Age: 8-17 (13.0 \pm 2.5$)$

ADHD: 21

McLeod et al. (13), Neuroimage Clin, 2014, Canada
Age: 8-17 (12.5 \pm 2.9$)$

DCD + ADHD: 18

Age: $8-17$ (11.5 \pm 3.0$)$

TDC: 23

Age: 8-17 (11.3 \pm 2.8$)$
DCD: MABC- $2>16^{\text {th }}$

percentile,

IQ $>80$

ADHD: Being diagnosed

as having ADHD according to the DSM-V criteria
Atypical neural connections were found in the sensory-motor cortex, cerebellum, and basal ganglion areas in the DCD group and DCD $+\mathrm{ADHD}$ group compared to the TDC group 
Table 1. continued

\begin{tabular}{|c|c|c|c|c|}
\hline $\begin{array}{l}\text { First author, } \\
\text { journal, year, } \\
\text { country }\end{array}$ & $\begin{array}{l}\text { Participants (number, } \\
\text { age range, mean age) }\end{array}$ & $\begin{array}{l}\text { Inclusion and } \\
\text { exclusion criteria }\end{array}$ & $\begin{array}{l}\text { Neuroimaging } \\
\text { technique }\end{array}$ & Neuroimaging results \\
\hline $\begin{array}{l}\text { Licari et al. (10), } \\
\text { Exp Brain Res, 2015, } \\
\text { Australia }\end{array}$ & $\begin{array}{l}\text { DCD: } 13 \\
\text { Age: } 8-10(9.6 \pm 0.8) \\
\text { TDC: } 13 \\
\text { Age: } 8-10(9.3 \pm 0.6)\end{array}$ & $\begin{array}{l}\text { DCD: MABC- } 2<5^{\text {th }} \\
\text { percentile, } \\
\text { TDC: MABC- } 2>15^{\text {th }} \\
\text { percentile } \\
\text { Not having a diagnosis } \\
\text { of ADHD }\end{array}$ & fMRI & $\begin{array}{l}\text { Less cortical activation was } \\
\text { detected in the right postcentral } \\
\text { gyrus and left superior and inferior } \\
\text { frontal gyri, and deficits were } \\
\text { observed in the mirror neuron } \\
\text { system in the DCD group }\end{array}$ \\
\hline $\begin{array}{l}\text { Biotteau et al. } \\
\text { (11), Eur Journal } \\
\text { of Paediatr Neurol, } \\
2017 \text {, France }\end{array}$ & $\begin{array}{l}\text { DCD: } 16 \\
\text { Age: } 8-12(9.6 \pm 1.7) \\
\text { DCD + DD: } 16 \\
\text { Age: } 8-12(9.9 \pm 1.1) \\
\text { TDC: } 16 \\
\text { Age: } 8-12(10.3 \pm 1.3)\end{array}$ & $\begin{array}{l}\text { DCD: MABC- } 2 \leq 5^{\text {th }} \\
\text { percentile } \\
\text { DD: MABC- } 2>16^{\text {th }} \\
\text { percentile } \\
\text { IQ }>85 \\
\text { Not having a diagnosis } \\
\text { of ADHD }\end{array}$ & fMRI & $\begin{array}{l}\text { Increased activation was found in } \\
\text { the premotor cortex in the DCD } \\
\text { and DD groups }\end{array}$ \\
\hline $\begin{array}{l}\text { Mcleod et al. ( } 55) \text {, } \\
\text { Neuroimage Clin, } \\
\text { 2016, Canada }\end{array}$ & $\begin{array}{l}\text { DCD: } 6 \\
\text { Age: } 8-16(13 \pm 2.8) \\
\text { DCD + ADHD: } 14 \\
\text { Age: } 8-16(11.3 \pm 3.8) \\
\text { ADHD: } 19 \\
\text { Age: } 8-16(12.4 \pm 3.1) \\
\text { TDC: } 21 \\
\text { Age: } 8-16(11 \pm 2.8)\end{array}$ & $\begin{array}{l}\text { DCD: MABC- } 2<16^{\text {th }} \\
\text { percentile, } \\
\text { ADHD: Being diagnosed } \\
\text { as having ADHD } \\
\text { according to the DSM-V } \\
\text { criteria }\end{array}$ & fMRI & $\begin{array}{l}\text { A stronger connection was found } \\
\text { between the middle frontal gyrus } \\
\text { and inferior lateral occipital cortex } \\
\text { and the left sensory-motor cortex in } \\
\text { the DCD + ADHD group compared } \\
\text { to the right sensory-motor cortex. } \\
\text { On the other hand, an equal } \\
\text { connection was found between the } \\
\text { middle frontal gyrus and inferior } \\
\text { lateral occipital cortex and the right } \\
\text { and left sensory-motor cortex in the } \\
\text { TDC, DCD, and ADHD groups }\end{array}$ \\
\hline $\begin{array}{l}\text { Thornton et al. (56), } \\
\text { Hum Mov Sci, 2018, } \\
\text { Canada }\end{array}$ & $\begin{array}{l}\text { DCD: } 9 \\
\text { Age: } 8-12(10.55 \pm 1.67) \\
\text { DCD + ADHD: } 18 \\
\text { Age: } 8-12(10.94 \pm 2.62) \\
\text { ADHD: } 20 \\
\text { Age: } 8-16(13.5 \pm 2.74) \\
\text { TDC: } 20 \\
\text { Age: } 8-12(10.2 \pm 2.8)\end{array}$ & $\begin{array}{l}\text { DCD: MABC- } 2<16^{\text {th }} \\
\text { percentile, } \\
\text { ADHD: Being diagnosed } \\
\text { as having ADHD } \\
\text { according to the DSM-V } \\
\text { criteria }\end{array}$ & fMRI & $\begin{array}{l}\text { Less activation was detected in the } \\
\text { primary sensory and motor cortex } \\
\text { areas of the DCD, DCD + ADHD, } \\
\text { and ADHD groups compared to the } \\
\text { TDC group }\end{array}$ \\
\hline $\begin{array}{l}\text { Reynolds et al. (54), } \\
\text { Int J Dev Neurosci, } \\
2015 \text {, } \\
\text { Australia }\end{array}$ & $\begin{array}{l}\text { DCD: } 10 \\
\text { Age: } 8-12(10.18 \pm 1.3) \\
\text { TDC: } 9 \\
\text { Age: } 8-12(10.4 \pm 1.17)\end{array}$ & $\begin{array}{l}\text { DCD: MABC- } 2<16^{\text {th }} \\
\text { percentile } \\
\text { TDC: MABC- } 2>25^{\text {th }} \\
\text { percentile }\end{array}$ & fMRI & $\begin{array}{l}\text { It was determined that there were } \\
\text { deficits in the mirror neuron system } \\
\text { in the DCD group, and therefore } \\
\text { it was suggested that children } \\
\text { with DCD had problems in motor } \\
\text { imaging }\end{array}$ \\
\hline $\begin{array}{l}\text { Lloyd et al. (16), } \\
\text { Magn Reson Med, } \\
\text { 2010, UK }\end{array}$ & $\begin{array}{l}\text { DCD: } 14 \\
\text { Age: } 8-13(10.7 \pm 2.7)\end{array}$ & $\begin{array}{l}\text { DCD: MABC- } 2<16^{\text {th }} \\
\text { percentile }\end{array}$ & MRI & $\begin{array}{l}\text { A negative correlation was found } \\
\text { between the cerebellar posterior } \\
\text { lobe gray matter volume and the } \\
\text { root mean square error score }\end{array}$ \\
\hline $\begin{array}{l}\text { Langevin et al. (18), } \\
\text { Dev Med Child } \\
\text { Neurol, } \\
\text { 2015, Canada }\end{array}$ & $\begin{array}{l}\text { DCD: } 14 \\
\text { Age: } 8-17(9.9 \pm 1.7) \\
\text { DCD + ADHD: } 10 \\
\text { Age: } 8-17(9.7 \pm 2.3) \\
\text { ADHD: } 10 \\
\text { Age: } 8-17(9.9 \pm 1.3) \\
\text { TDC: } 14 \\
\text { Age: } 8-17(11.2 \pm 3)\end{array}$ & $\begin{array}{l}\text { DCD: MABC- } 2<16^{\text {th }} \\
\text { percentile } \\
\text { TDC: MABC- } 2>25^{\text {th }} \\
\text { percentile } \\
\text { ADHD: Being diagnosed } \\
\text { as having ADHD } \\
\text { according to the DSM-V } \\
\text { criteria }\end{array}$ & MRI & $\begin{array}{l}\text { Less parietal, temporal and frontal } \\
\text { cortical thickness was detected in } \\
\text { the DCD + ADHD group compared } \\
\text { to the other groups }\end{array}$ \\
\hline
\end{tabular}


Table 1. continued

\begin{tabular}{|c|c|c|c|c|}
\hline $\begin{array}{l}\text { First author, } \\
\text { journal, year, } \\
\text { country }\end{array}$ & $\begin{array}{l}\text { Participants (number, } \\
\text { age range, mean age) }\end{array}$ & $\begin{array}{l}\text { Inclusion and } \\
\text { exclusion criteria }\end{array}$ & $\begin{array}{l}\text { Neuroimaging } \\
\text { technique }\end{array}$ & Neuroimaging results \\
\hline $\begin{array}{l}\text { Caeyenberghs et al. } \\
(17) \text {, } \\
\text { Dev Sci, 2016, } \\
\text { Australia }\end{array}$ & $\begin{array}{l}\text { DCD: } 11 \\
\text { ASD: } 15 \\
\text { DCD + ASD: } 8 \\
\text { TDC: } 19 \\
\text { Age: } 8-12 \text { years }\end{array}$ & $\begin{array}{l}\text { DCD: Being diagnosed } \\
\text { as having DCD } \\
\text { according to the DSM-IV } \\
\text { criteria } \\
\text { IQ }>75\end{array}$ & MRI & $\begin{array}{l}\text { There was a difference between the } \\
\text { DCD, ASD and DCD + ASD groups } \\
\text { and TDC in terms of the clustering } \\
\text { coefficient of brain gray matter } \\
\text { volume, which was an indicator of } \\
\text { brain connections. } \\
\text { An increase in clustering coefficient } \\
\text { was detected in the right inferior } \\
\text { frontal gyrus in the ASD group, in } \\
\text { the right lateral orbitofrontal cortex } \\
\text { in the DCD group, and in the left } \\
\text { temporal cortex and right medial } \\
\text { orbitofrontal cortex in the DCD + } \\
\text { ASD group } \\
\text { It has been found that increase } \\
\text { in clustering coefficient indicates } \\
\text { dysfunction in neural mechanisms } \\
\text { and is associated with poor } \\
\text { performance in motor tasks }\end{array}$ \\
\hline $\begin{array}{l}\text { Reynolds et al. (61), } \\
\text { Int J Dev Neurosci, } \\
2017 \text {, Australia }\end{array}$ & $\begin{array}{l}\text { DCD: } 22 \\
\text { Age: } 8-12(9.9 \pm 1.1) \\
\text { TDC: } 22 \\
\text { Age: } 8-12(9.7 \pm 1.2)\end{array}$ & $\begin{array}{l}\text { DCD: MABC- } 2<16^{\text {th }} \\
\text { percentile } \\
\text { TDC: MABC- } 2>25^{\text {th }} \\
\text { percentile } \\
\text { Not having a diagnosis } \\
\text { of ADHD }\end{array}$ & MRI & $\begin{array}{l}\text { It was determined that the gray } \\
\text { matter volume in the frontal cortex } \\
\text { of children with DCD was lower } \\
\text { than the TDC }\end{array}$ \\
\hline $\begin{array}{l}\text { Zwicker et al. (24), } \\
\text { Pediatr Neurol, 2012, } \\
\text { Canada }\end{array}$ & $\begin{array}{l}\text { DCD: } 7 \\
\text { Age: } 8-12(10.2 \pm 1.6) \\
\text { TDC: } 9 \\
\text { Age: } 8-12(10.4 \pm 1.7)\end{array}$ & $\begin{array}{l}\text { DCD: MABC- } 2<16^{\text {th }} \\
\text { percentile } \\
\text { Kaufmann Brief } \\
\text { Intelligence test }>80 \\
\text { Conner Attention- } \\
\text { Deficit/Hyperactivity } \\
\text { Disorder Diagnostic } \\
\text { scale }<70\end{array}$ & DTI & $\begin{array}{l}\text { The average diffusion amount in } \\
\text { the corticospinal tract was found } \\
\text { to be lower in children with DCD } \\
\text { than in TDC } \\
\text { A positive correlation was found } \\
\text { between axial white matter } \\
\text { diffusion and MABC-2 scores }\end{array}$ \\
\hline $\begin{array}{l}\text { Langevin et al. (14), } \\
\text { J Pediatr, 2014, } \\
\text { Canada }\end{array}$ & $\begin{array}{l}\text { DCD: } 9 \\
\text { Age: } 8-12(11.5 \pm 3.18) \\
\text { ADHD: } 23 \\
\text { Age: } 8-12(12.22 \pm 2.68) \\
\text { DCD + ADHD: } 26 \\
\text { Age: } 8-12(11.78 \pm 2.99)\end{array}$ & $\begin{array}{l}\text { DCD: MABC- } 2<16^{\text {th }} \\
\text { percentile } \\
\text { ADHD: Conners' Parent } \\
\text { Rating scale }>95^{\text {th }} \\
\text { percentile }\end{array}$ & DTI & $\begin{array}{l}\text { Decreased white matter diffusion } \\
\text { in the parietal lobe in children with } \\
\text { DCD } \\
\text { Decreased white matter diffusion } \\
\text { was found in the frontal lobe in } \\
\text { children with ADHD } \\
\text { Decreased white matter diffusion } \\
\text { was found in both parietal and } \\
\text { frontal lobes in children with DCD } \\
+ \text { ADHD }\end{array}$ \\
\hline $\begin{array}{l}\text { Williams et al. (25), } \\
\text { Neuroreport, } 2017 \text {, } \\
\text { Australia }\end{array}$ & $\begin{array}{l}\text { DCD: } 7 \\
\text { Age: } 18-40(24.5 \pm 7.6) \\
\text { Control group: } 9 \\
\text { Age: } 18-40(26.7 \pm 5.5)\end{array}$ & $\begin{array}{l}\text { DCD: McCarron } \\
\text { Assessment of } \\
\text { Neuromuscular } \\
\text { Development } \leq 85 \\
\text { Not having a diagnosis } \\
\text { of autism, Asperger's } \\
\text { syndrome or ADHD } \\
\text { Control group: } \\
\text { McCarron Assessment } \\
\text { of Neuromuscular } \\
\text { Development }>85 \\
\text { Not having a diagnosis } \\
\text { of autism, Asperger's } \\
\text { syndrome or ADHD }\end{array}$ & DTI & $\begin{array}{l}\text { A significant decrease was detected } \\
\text { in the fractional anisotropy of white } \\
\text { matter in the corticospinal tract and } \\
\text { superior longitudinal fasciculus in } \\
\text { the DCD group, and there was a } \\
\text { significant decrease in the mean } \\
\text { diffusion amount of white matter } \\
\text { in the internal capsule and inferior } \\
\text { longitudinal fasciculus in the DCD } \\
\text { group compared to the control } \\
\text { group }\end{array}$ \\
\hline
\end{tabular}


Table 1 . continued

\begin{tabular}{|c|c|c|c|c|}
\hline $\begin{array}{l}\text { First author, } \\
\text { journal, year, } \\
\text { country }\end{array}$ & $\begin{array}{l}\text { Participants (number, } \\
\text { age range, mean age) }\end{array}$ & $\begin{array}{l}\text { Inclusion and } \\
\text { exclusion criteria }\end{array}$ & $\begin{array}{l}\text { Neuroimaging } \\
\text { technique }\end{array}$ & Neuroimaging results \\
\hline $\begin{array}{l}\text { Debrabant et al. } \\
\text { (15), } \\
\text { J Pediatr, 2016, } \\
\text { Belgium }\end{array}$ & $\begin{array}{l}\text { DCD: } 21 \\
\text { Age: } 8-10 \text { years } \\
(9.2 \pm 1.1) \\
\text { TDC: } 20 \\
\text { Age: } 8-10 \text { years } \\
(9.4 \pm 1.7)\end{array}$ & $\begin{array}{l}\text { DCD: MABC- } 2 \leq 5^{\text {th }} \\
\text { percentile }\end{array}$ & DTI & $\begin{array}{l}\text { White matter diffusion in the } \\
\text { visual-motor tracts was lower in the } \\
\text { DCD group }\end{array}$ \\
\hline $\begin{array}{l}\text { Hyde et al. (26), } \\
\text { Neuroimage Clin, } \\
\text { 2018, Australia }\end{array}$ & $\begin{array}{l}\text { DCD: } 7 \\
\text { Age: } 18-46 \text { years } \\
(23.29 \pm 4.31) \\
\text { Control group: } 20 \\
\text { Age: } 18-46 \text { years } \\
(26.16 \pm 4.34)\end{array}$ & $\begin{array}{l}\text { DCD: Being diagnosed } \\
\text { as having DCD } \\
\text { according to the DSM-V } \\
\text { criteria }\end{array}$ & DTI & $\begin{array}{l}\text { Axon diameters and numbers } \\
\text { in the left Superior Longitudinal } \\
\text { Fasciculus were lower than the } \\
\text { control group, while a decrease in } \\
\text { the volume of the right Superior } \\
\text { Longitudinal Fasciculus was also } \\
\text { detected in the DCD group. A } \\
\text { positive correlation was found } \\
\text { between this decrease and } \\
\text { deficiencies in motor skills }\end{array}$ \\
\hline $\begin{array}{l}\text { Lust et al. (53), } \\
\text { Child Care Health } \\
\text { Dev, 2006, Holland }\end{array}$ & $\begin{array}{l}\text { DCD: } 10 \\
\text { Age: } 8-12 \text { years } \\
(10.4 \pm 1.1) \\
\text { TDC: } 7 \\
\text { Age: } 8-12 \text { years } \\
(9.6 \pm 1.7) \\
\text { Adult group: } 14 \\
\text { Age: } 19-29 \text { years } \\
(22.4 \pm 4.7)\end{array}$ & $\begin{array}{l}\text { DCD: MABC- } 2<16^{\text {th }} \\
\text { percentile }\end{array}$ & EEG & $\begin{array}{l}\text { In the test estimating the right and } \\
\text { left hand pictures rotated in } 45 \\
\text { degrees in right and left directions; } \\
\text { while accurate prediction, response } \\
\text { times and EEG activations were } \\
\text { found similar in the DCD and } \\
\text { TDC groups, better results were } \\
\text { obtained in the adult group and } \\
\text { it was found that this test showed } \\
\text { age-related changes }\end{array}$ \\
\hline $\begin{array}{l}\text { DeCastalneu et al. } \\
\text { (31), Hum Mov Sci, } \\
\text { 2008, France }\end{array}$ & $\begin{array}{l}\text { DCD: } 24 \\
\text { ( } 3 \text { age groups of } 8-9, \\
10-11 \text { and } 12-13 \text { years) } \\
\text { TDC: } 24 \\
\text { ( } 3 \text { age groups of } 8-9, \\
10-11 \text { and } 12-13 \text { years) }\end{array}$ & $\begin{array}{l}\text { DCD: Being diagnosed } \\
\text { as having DCD } \\
\text { according to the DSM-V } \\
\text { criteria } \\
\text { MABC- } 2 \leq 5^{\text {th }} \text { percentile } \\
\text { IQ }>80\end{array}$ & EEG & $\begin{array}{l}\text { According to the EEG findings, it } \\
\text { was found that intrahemispheric } \\
\text { connections between the frontal- } \\
\text { central areas increased more in } \\
\text { only the 8-9 age group with DCD } \\
\text { compared to the other groups } \\
\text { According to these findings, it } \\
\text { appeared that younger children } \\
\text { with DCD needed a high level of } \\
\text { pre-programming to compensate } \\
\text { for difficulties in perceptual- } \\
\text { motor and executive functions of } \\
\text { movement related to coordination } \\
\text { disorders } \\
\text { No significant difference was found } \\
\text { between the groups according to } \\
\text { EEG findings for interhemispheric } \\
\text { connections }\end{array}$ \\
\hline $\begin{array}{l}\text { Tsai et al. (35), } \\
\text { Dev Med Child } \\
\text { Neurol, 2012, } \\
\text { Taiwan }\end{array}$ & $\begin{array}{l}\text { DCD: } 24 \\
\text { Age: } 8-16 \text { years } \\
(11.4 \pm 2.1) \\
\text { TDC: } 30 \\
\text { Age: } 8-16 \text { years } \\
(11.8 \pm 2.7)\end{array}$ & $\begin{array}{l}\text { DCD: MABC- }-5^{\text {th }} \\
\text { percentile } \\
\text { Not being diagnosed as } \\
\text { having autism or ADHD }\end{array}$ & EEG & $\begin{array}{l}\text { It was found that children with } \\
\text { DCD had a prolonged reaction } \\
\text { time and EEG activation was lower } \\
\text { than TDC, and it was observed } \\
\text { that children with DCD made } \\
\text { less effort in the evaluation and } \\
\text { response process and used less } \\
\text { neural resources to compensate for } \\
\text { mistakes }\end{array}$ \\
\hline
\end{tabular}


Table 1. continued

\begin{tabular}{|c|c|c|c|c|}
\hline $\begin{array}{l}\text { First author, } \\
\text { journal, year, } \\
\text { country }\end{array}$ & $\begin{array}{l}\text { Participants (number, } \\
\text { age range, mean age) }\end{array}$ & $\begin{array}{l}\text { Inclusion and } \\
\text { exclusion criteria }\end{array}$ & $\begin{array}{l}\text { Neuroimaging } \\
\text { technique }\end{array}$ & Neuroimaging results \\
\hline $\begin{array}{l}\text { Pangelinan et al. } \\
\text { (36), J Neurophysiol, } \\
\text { 2013, France }\end{array}$ & $\begin{array}{l}\text { DCD: } 14 \\
\text { Age: } 6-12 \text { years } \\
(10.2 \pm 2.1) \\
\text { TDC: } 20 \\
\text { Age: } 6-12 \text { years } \\
(9.8 \pm 2.2)\end{array}$ & $\begin{array}{l}\text { DCD: MABC- } 2 \leq 5^{\text {th }} \\
\text { percentile } \\
\text { The patients whose } \\
\text { dominant hand was } \\
\text { found to be the right } \\
\text { hand according to the } \\
\text { Fagard and Corroyer } \\
2003 \text { Handedness test } \\
\text { TDC: MABC2 } \geq 25^{\text {th }} \\
\text { percentile } \\
\text { Those who did not } \\
\text { have developmental, } \\
\text { neurological and } \\
\text { learning problems and } \\
\text { were right-handed }\end{array}$ & EEG & $\begin{array}{l}\text { Younger children (6-8 years) with } \\
\text { DCD had less cortical activation } \\
\text { areas and lower EEG frequency } \\
\text { amplitudes. Compensatory cortical } \\
\text { activation areas were found to } \\
\text { be more and EEG frequency } \\
\text { amplitudes higher in older patients } \\
\text { with DCD (10-12 years) } \\
\text { It has been determined that this } \\
\text { behavioral change is to show better } \\
\text { motor performance }\end{array}$ \\
\hline $\begin{array}{l}\text { Fong et al. (41), } \\
\text { Medicine } \\
\text { (Baltimore), 2016, } \\
\text { China }\end{array}$ & $\begin{array}{l}\text { DCD: } 86 \\
\text { Age: } 6-10 \text { years } \\
(7.9 \pm 1.7) \\
\text { TDC: } 99 \\
\text { Age: } 6-10 \text { years } \\
(7.4 \pm 1.6)\end{array}$ & $\begin{array}{l}\text { DCD: MABC- } 2 \leq 5^{\text {th }} \\
\text { percentile } \\
\text { Bruininks-Oseretsky Test } \\
\text { of motor proficiency } \leq 42\end{array}$ & EEG & $\begin{array}{l}\text { EEG values of children with DCD } \\
\text { were found to be lower than the } \\
\text { TDC group }\end{array}$ \\
\hline $\begin{array}{l}\text { Blais et al. (44), } \\
\text { Dev Sci, 2018, } \\
\text { France }\end{array}$ & $\begin{array}{l}\text { DCD: } 10 \\
\text { Age: } 12-16 \text { years } \\
(13.49 \pm 1.76) \\
\text { TDC: } 10 \\
\text { Age: } 12-16 \text { years } \\
(13.47 \pm 1.39)\end{array}$ & $\begin{array}{l}\text { DCD: MABC- } 2 \leq 5^{\text {th }} \\
\text { percentile } \\
\text { Not having a diagnosis } \\
\text { of ADHD according to } \\
\text { the DSM- } 5 \text { criteria }\end{array}$ & EEG & $\begin{array}{l}\text { According to the EEG findings, } \\
\text { the intrahemispheric connections } \\
\text { of both groups were found to } \\
\text { be similar, while the number of } \\
\text { interhemispheric connections of the } \\
\text { DCD group was found to be lower } \\
\text { than the TDC group }\end{array}$ \\
\hline $\begin{array}{l}\text { Koch et al. (49), } \\
\text { Exp Brain Res, 2018, } \\
\text { Portugal }\end{array}$ & $\begin{array}{l}\text { DCD: } 10 \\
\text { Age: } 8-12 \text { years } \\
(9.9 \pm 1.2) \\
\text { TDC: } 10 \\
\text { Age: } 8-12 \text { years } \\
(10.01 \pm 1.1)\end{array}$ & $\begin{array}{l}\text { DCD: MABC- } \leq \leq 5^{\text {th }} \\
\text { percentile } \\
\text { TDC: MABC } 2 \geq 25^{\text {th }} \\
\text { percentile } \\
\text { Those who did not } \\
\text { have developmental, } \\
\text { neurological or learning } \\
\text { problems }\end{array}$ & NIRS & $\begin{array}{l}\text { Dorsolateral prefrontal cortex } \\
\text { activation was found to be higher } \\
\text { in children with DCD compared to } \\
\text { TDC }\end{array}$ \\
\hline $\begin{array}{l}\text { Caçola et al. (50), } \\
\text { Int J Dev Neurosci, } \\
\text { 2018, USA }\end{array}$ & $\begin{array}{l}\text { DCD: } 10 \\
\text { Age: } 8-12 \text { years } \\
(8.46 \pm 0.97) \\
\text { TDC: } 10 \\
\text { Age: } 8-12 \text { years } \\
(8.22 \pm 0.86)\end{array}$ & $\begin{array}{l}\text { DCD: } \text { MABC- } 2 \leq 5^{\text {th }} \\
\text { percentile } \\
\text { TDC: MABC } 2 \geq 25^{\text {th }} \\
\text { percentile } \\
\text { Those who did not } \\
\text { have developmental, } \\
\text { neurological or learning } \\
\text { problems }\end{array}$ & fNIRS & $\begin{array}{l}\text { According to fNIRS findings, it was } \\
\text { determined that there was more } \\
\text { activation in the primary motor } \\
\text { cortex and premotor cortex areas } \\
\text { in the TDC group compared to the } \\
\text { DCD group, both contralateral and } \\
\text { ipsilatereral } \\
\text { In addition, it was observed that } \\
\text { the activated areas in the DCD } \\
\text { group were mostly in the ipsilateral } \\
\text { direction }\end{array}$ \\
\hline
\end{tabular}




\section{Functional Near-infrared Spectroscopy}

Although few fNIRS studies have been conducted on children with DCD, it is seen that there are differences in interhemispheric connections, and neural connections are more ipsilateral in children with DCD compared with those with typical development $(49,50)$.

\section{Conclusion}

Advanced neuroimaging techniques provide a better understanding of the neural connections in DCD and detailed information about brain structure and function. However, due to the small sample sizes in the studies, no clear result could be reached to explain the underlying mechanism. The limitations of the review are that one study was in French and full texts of two studies were not available and thus could not be included. There is no consensus on the neuroradiology of DCD in the literature because the results of the studies discussed in the review vary. It is also necessary to conduct multi-center studies that better demonstrate the relationship between these different radiologic findings and clinical findings. With these studies, it is thought that the most effective methods for the treatment of DCD can be determined by guiding neuroimaging studies, physiotherapy/ occupational therapy, and other intervention methods.

\section{Ethics}

Peer-review: Externally peer-reviewed.

\section{Authorship Contributions}

Design: C.Y., G.A., M.G.P., Data Collection or Processing: C.Y., G.A., Analysis or Interpretation: C.Y., G.A., M.G.P., E.M., R.K., C.G.Y., Literature Search: E.M., R.K., C.G.Y., Writing: C.Y., G.A., M.G.P., E.M., R.K., C.G.Y.

Conflict of Interest: No conflict of interest was declared by the authors.

Financial Disclosure: The authors declared that this study received no financial support.

\section{References}

1. American Psychiatric Association. Diagnostic and Statistical Manual of Mental Disorders (DSM-5). 5th ed. Washington, DC: American Psychiatric Publishing, 2013.

2. Zwicker JG, Harris SR, Klassen AF. Quality of life domains affected in children with developmental coordination disorder: A systematic review. Child Care Health Dev 2013;39:562-580.

3. Kirby A, Williams N, Thomas M, Hill EL. Self-reported mood, general health, wellbeing and employment status in adults with suspected DCD. Res Dev Disabil 2013;34:1357-1364.

4. Steinbrink J, Villringer A, Kempf F, et al. Illuminating the BOLD signal: Combined fMRG-fNIRS studies. Journal of Magn Reson Imaging 2006;24:495-505.

5. Querne L, Berquin P, Vernier-Hauvette MP, et al. Dysfunction of the attentional brain network in children with developmental coordination disorder: a fMRG study. Brain Res 2008;1244:89-102.

6. Kashiwagi M, Iwaki S, Narumi Y, Tamai H, Suzuki S. Paryetal dysfunction in developmental coordination disorder: a functional MRI study. Neuroreport 2009;20:1319-1324.

7. Zwicker JG, Missiuna C, Harris SR, Boyd LA. Brain activation of children with developmental coordination disorder is different than peers. Pediatrics 2010;126:e678-e686.

8. Zwicker JG, Missiuna C, Harris SR, Boyd LA. Brain activation associated with motor skill practice in children with developmental coordination disorder: an fMRG study. Int J Dev Neurosci 2011;29:145-152.
9. Debrabant J, Gheysen F, Caeyenberghs K, Van Waelvelde H, Vingerhoets G. Neural underpinnings of impaired predictive motor timing in children with Developmental Coordination Disorder. Res Dev Disabil 2013;34:14781487

10. Licari MK, Billington J, Reid SL, et al. Cortical functioning in children with developmental coordination disorder: a motor overflow study. Exp Brain Res 2015;233:1703-1710.

11. Biotteau M, Péran P, Vayssière $\mathrm{N}$, et al. Neural changes associated to procedural learning and automatization process in developmental coordination disorder and/or developmental dyslexia. Eur J Paediatr Neurol 2017;21:286-299.

12. Barkovich AJ, Raybaud C, (eds). Pediatrics Neuroimaging. 5th ed. Lippincott Williams \& Wilkins, 2011.

13. McLeod KR, Langevin LM, Goodyear BG, Dewey D. Functional connectivity of neural motor networks is disrupted in children with developmental coordination disorder and attention-deficit/hyperactivity disorder. Neuroimage Clin 2014;4:566-575.

14. Langevin LM, MacMaster FP, Crawford S, Lebel C, Dewey D. Common white matter microstructure alterations in pediatric motor and attention disorders. J Pediatr 2014; 164:1157-1164.

15. Debrabant J, Vingerhoets G, Van Waelvelde H, et al. Brain connectomics of visual-motor deficits in children with developmental coordination disorder. J Pediatr 2016;169:21-27.

16. Lloyd W, Mon-Williams M, Waiter GD, Williams JH. Developmental coordination disorder: A voxel-based MRI study of neural correlates. Magn Reson Med 2010;18:1.

17. Caeyenberghs K, Taymans T, Wilson $\mathrm{PH}$, et al. Neural signature of developmental coordination disorder in the structural connectome independent of comorbid autism. Dev Sci 2016;19:599-612.

18. Langevin LM, MacMaster FP, Dewey D. Distinct patterns of cortical thinning in concurrent motor and attention disorders. Dev Med Child Neurol 2015;57:257-264.

19. Abernethy LJ, Cooke RW, Foulder-Hughes L. Caudate and hippocampal volumes, intelligence, and motor impairment in 7-year-old children who were born preterm. Pediatr Res 2004;55:884-893.

20. Skranes J, Evensen KI, L $\varnothing$ haugen GC, et al. Abnormal cerebral MRI findings and neuroimpairments in very low birth weight (VLBW) adolescents. Eur J Paediatr Neurol 2008;12:273-283.

21. Van Kooij BJ, de Vries LS, Ball G, et al. Neonatal tract-based spatial statistics findings and outcome in preterm infants. AJNR Am J Neuroradiol 2012;33:188-194.

22. Beaulieu $C$. The basis of anisotropic water diffusion in the nervous system-a technical review. NMR Biomed 2002;15:435-455.

23. Snook L, Paulson LA, Roy D, Phillips L, Beaulieu C. Diffusion tensor imaging of neurodevelopment in children and young adults. Neuroimage 2005;26:1164-1173.

24. Zwicker JG, Missiuna C, Harris SR, Boyd LA. Developmental coordination disorder: a pilot diffusion tensor imaging study. Pediatr Neurol 2012;46:162-167.

25. Williams J, Kashuk SR, Wilson PH, Thorpe G, Egan GF. White matter alterations in adults with probable developmental coordination disorder: An MRI diffusion tensor imaging study. Neuroreport 2017;28:87-92.

26. Hyde C, Fuelscher I, Enticott PG, et al. White matter organization in developmental coordination disorder: A pilot study exploring the added value of constrained spherical deconvolution. Neuroimage Clin 2018;21:1025.

27. Dewey D, Cantell M, Crawford SG. Motor and gestural performance in children with autism spectrum disorders, developmental coordination disorder, and/or attention deficit hyperactivity disorder. J Int Neuropsychol Soc 2007; 13:246-256.

28. Zatorre RJ, Fields RD, Johansen-Berg H. Plasticity in gray and white: neuroimaging changes in brain structure during learning. Nat Neurosci 2012;15:528-536.

29. Brown-Lum M, Zwicker JG. Brain imaging increases our understanding of developmental coordination disorder: a review of literature and future directions. Curr Dev Disord Rep 2015;2:131-140. 
30. Niedermeyer E, da Silva F. Electroencephalography: basic principles, clinical applications, and related fields. Philadelphia: Lippincott Williams \& Wilkins; 2005.

31. DeCastelnau P, Albaret JM, Chaix Y, Zanone PG. A study of EEG coherence in DCD children during motor synchronization task. Hum Mov Sci 2008;27:230-241.

32. Albaret J-M, Chaix Y. Neurobiological bases and neurophysiological correlates of developmental coordination disorders. Clin Neurophysiol 2011;42:11-17.

33. Alloway TP, Temple KJ. A comparison of working memory profiles and learning in children with developmental coordination disorder and moderate learning difficulties. Appl Cognitive Psych 2007;21:473-487.

34. Baddeley AD. The episodic buffer: A new component of working memory? Trends Cogn Sci 2000;4:417-423.

35. Tsai C, Chang Y, Hung T, Tseng Y, Chen T. The neurophysiological performance of visuospatial working memory in children with developmental coordination disorder. Dev Med Child Neurol 2012;54:1114-1120.

36. Pangelinan MM, Hatfield BD, Clark JE. Differences in movement-related cortical activation patterns underlying motor performance in children with and without developmental coordination disorder. J Neurophysiol 2013;109:3041-3050.

37. Barkley RA. The nature of ADHD. Attention Deficit Hyperactivity Disorder. A Handbook for Diagnosis and Treatment. New York: Guilford Press; 1990:3-9.

38. Piek JP, Dyck MJ, Nieman A, et al. The relationship between motor coordination, executive functioning and attention in school aged children. Arch Clin Neuropsychol 2004;19:1063-1076.

39. Wilmut K, Brown JH, Wann JP. Attention disengagement in children with developmental coordination disorder. Disabil Rehabil 2007;29:47-55.

40. Lohse KR, Sherwood DE, Healy AF. Neuromuscular effects of shifting the focus of attention in a simple force production task. J Mot Behav 2011;43:173-184.

41. Fong SS, Chung JW, Cheng YT, et al. Attention during functional tasks is associated with motor performance in children with developmental coordination disorder: A cross-sectional study. Medicine (Baltimore) 2016;95:37.

42. Gheysen F, Van Waelvelde H, Fias W. Impaired visuo-motor sequence learning in developmental coordination disorder. Res Dev Disabil 2011;32:749-756.

43. Serrien DJ. Coordination constraints during bimanual versus unimanual performance conditions. Neuropsychologia 2008;46:419-425.

44. Blais M, Amarantini D, Albaret JM, Chaix Y, Tallet J. Atypical interhemispheric communication correlates with altered motor inhibition during learning of a new bimanual coordination pattern in developmental coordination disorder. Dev Sci 2018;21:121-163.

45. Licari M, Larkin D. Increased associated movements: Influence of attention deficits and movement difficulties. Hum Mov Sci 2008;27:310-324.

46. Licari M, Larkin, D, Miyahara M. The influence of developmental coordination disorder and attention deficits on associated movements in children. Hum Mov Sci 2006;25:90-99.
47. Tallet J, Albaret JM, Barral J. Developmental changes in lateralized inhibition of symmetric movements in children with and without developmental coordination disorder. Res Dev Disabil 2013;34:2523-2532.

48. Quaresima V, Bisconti S, Ferrari M. A brief review on the use of functional near-infrared spectroscopy (fNIRS) for language imaging studies in human newborns and adults. Brain Lang 2012;121:79-89.

49. Koch JKL, Miguel H, Smiley-Oyen AL. Prefrontal activation during Stroop and Wisconsin card sort tasks in children with developmental coordination disorder: a NIRS study. Exp Brain Res 2018;236:3053-3064.

50. Caçola P, Getchell N, Srinivasan D, Alexandrakis G, Liu H. Cortical activity in fine-motor tasks in children with Developmental Coordination Disorder: A preliminary fNIRS study. Int J Dev Neurosci 2018;65:83-90.

51. Sigmundsson H. Perceptual deficits in clumsy children: Inter-and intramodal matching approach-a window into clumsy behavior. Neural Plas 2003;10:27-38.

52. De Castelnau P, Albaret JM, Chaix Y, Zanone PG. A study of EEG coherence in DCD children during motor synchronization task. Hum Mov Sci 2008;27:230-241.

53. Lust JM, Geuze RH, Wijers AA, Wilson PH. An EEG study of mental rotation-related negativity in children with Developmental Coordination Disorder. Child Care Health Dev 2006;32:649-663.

54. Reynolds JE, Licari MK, Billington J, et al. Mirror neuron activation in children with developmental coordination disorder: a functional MRI study. Int J Dev Neurosci 2015;47:309-319.

55. McLeod KR, Langevin LM, Dewey D, Goodyear BG. Atypical within-and between-hemisphere motor network functional connections in children with developmental coordination disorder and attention-deficit/hyperactivity disorder. Neuroimage Clin 2016;12:157-164.

56. Thornton S, Bra, S, Langevin LM, Dewey D. Functional brain correlates of motor response inhibition in children with developmental coordination disorder and attention eficit/hyperactivity disorder. Hum Mov Sci 2018;59:134-142.

57. Fogassi L, Luppino G. Motor functions of the parietal lobe. Curr Opin Neurobiol 2005;15:626-631.

58. Farah MJ, Wong AB, Monheit MA, Morrow LA. Parietal lobe mechanisms of spatial attention: Modality-specific or supramodal? Neuropsychologia 1989;27:461-470.

59. Middleton FA, Strick PL. Basal ganglia and cerebellar loops: motor and cognitive circuits. Brain Res Brain Res Rev 2000;31:236-250.

60. Blank R, Smits-Engelsman B, Polatajko H, Wilson P. European Academy for Childhood Disability (EACD): Recommendations on the definition, diagnosis and intervention of developmental coordination disorder (long version). Dev Med Child Neurol 2012;54:54-93.

61. Reynolds JE, Licari MK, Reid SL, et al. Reduced relative volume in motor and attention regions in developmental coordination disorder: A voxelbased morphometry study. Int J Dev Neurosci 2017;58:59-64. 